\title{
Introduction: Quotas - Add Women and Stir?
}

\author{
Mariz Tadros
}

\begin{abstract}
Quotas have become increasingly popular as a fast track option for securing enhanced political representation largely because of their proven impact on increasing the number of women in parliament. As more countries have adopted one form or another of the quota, it is now timely to reflect on what the implications have been for transforming gender relations and the nature of politics at large. This introduction examines from the country case studies presented in this IDS Bulletin, the insight offered into the dynamics of motorways and pathways of increasing women's decision-making power (with or without a quota) and the underlying assumptions about gender, power and politics as well as the policy issues for consideration.
\end{abstract}

\begin{abstract}
1 Introduction
Exactly ten years ago, at the Millennium Summit, world leaders announced a commitment to reducing extreme poverty through a series of time-bound targets encompassed within the Millennium Development Goals (MDGs), with a deadline of 2015 (UN 2006a). The third MDG was to promote gender equality and empower women and the 'proportion of seats held by women in national parliament (IPU)' was set as one of the key indicators for its achievement (UN 2006b). As the MDG Review Summit meets in September 2010 to assess progress, this is an opportunity to consider whether the proportion of women in parliament continues to be the most adequate proxy for women's political empowerment.
\end{abstract}

Fifteen years ago, in September 1995, the Beijing Platform of Action called upon governments to 'take positive action to build a critical mass of women leaders, executives and managers in strategic decision-making positions' (UN DAW n.d.). The critical mass for lobbying was established as at least 30 per cent of seats to be occupied by women in parliament. Some 25 years ago, the Nairobi Forward Looking Strategies for the Advancement of Women (UN 1985) put forward a broad and highly political goal enshrined in paragraph 51: 'The political commitment to establish, modify, expand or enforce a comprehensive legal base for the equality of women and men and on the basis of human dignity must be strengthened'. These international platforms have had an immense influence on the national contexts. It is striking that in virtually every country case study presented in this IDS Bulletin, there is reference to international frameworks, whether the MDGs, the CEDAW, the Beijing Platform of Action or the Nairobi Conference, in some capacity. Domestic engagements with gender and politics have been informed by international discourses, policies and programmes on approaches to women's political empowerment, both on local, regional and national levels. From the articles presented in this IDS Bulletin, this has manifested itself in multiple ways: on a policy level, it has influenced the choices of policy demands being advocated by activists; it has featured as a yardstick against which activists measure their own realities; a lobbying point for change (advocacy for national government compliance with treaties it has signed to or international norms it purports to); or as an entry point for bilateral or multilateral policy dialogue on gender issues. Donor-supported programmes aimed at helping countries put international frameworks in action have also both shaped the practical focus of efforts to empower women politically, as well as generated much controversy about their relevance, contextual appropriateness and effects. In view of both the overt and more nuanced ways in which international policy places emphases (such

IDS Bulletin Volume 41 Number 5 September 2010 (c) 2010 The Author. Journal compilation (? Institute of Development Studies Published by Blackwell Publishing Ltd, 9600 Garsington Road, Oxford OX4 2DQ, UK and 350 Main Street, Malden, MA 02148, USA 
as getting the numbers right as a way of redressing imbalances in gendered political representation), this IDS Bulletin hopes to contribute to the debate about understandings of gender and political power.

In recent years, the message for addressing gender inequalities in politics has focused on redressing the imbalance in the number of women and men in parliament. The quota has been gradually moving centre stage as the channel for women's accession to political decision-making power, largely because it has proven to increase numbers and because it has challenged the notion that countries in the South should pursue the same linear path of development that the Nordic countries have taken, should they aspire to have similar gender equity in parliament. Professor Dahlerup argues that:

A dramatic change has taken place recently in the global rank order of countries based on their level of female political representation. As a result of quota provisions, Rwanda, Costa Rica, Argentina, Mozambique and South Africa are now placed very high in the world league of the Inter-Parliamentary Union. The five Nordic states, Denmark, Finland, Iceland, Norway and Sweden, which for a long time were virtually alone at the top of the ranking table, are now being challenged. Although controversial, the electoral gender quota has proven to be a highly effective instrument for achieving equality, provided that it is implemented properly (Dahlerup 2003: 1).

This IDS Bulletin issue is devoted to exploring what the quota has meant as a motorway to women's accession to political power. It draws on research findings from the Pathways of Women's Empowerment Research Programme Consortium ('Pathways'), ${ }^{1}$ as well as a series of articles based on presentations given at a special seminar in the Brazilian National Congress coconvened by Ana Alice Alcântara Costa as part of the Pathways programme, and contributions from other country case studies. The articles presented here are diverse in their geographical setting, political level they focus on, context, and experiences. Julie Ballington presents an analysis of global trends in women's political representation in parliament, and the diversity in political paths pursued. Clara Araújo writes from Brazil and Montserrat Sagot from Costa
Rica, demonstrating two different results from the application of quotas at various administrative levels within these Latin American countries. From South Asia, country case studies on the path to, and the application of, quotas at the local government level are presented from Bangladesh by Sohela Nazneen and Sakiba Tasneem; from India by Divya Sharma and Ratna Sudarshan, and from Pakistan by Saba Gul Khattak. From subSaharan Africa, Hussaina Abdullah writes on the struggle for women's political leadership in Sierra Leone in the context of the absence of a quota, and in contrast, Juliana Kantengwa explains how Rwanda became a world leader in achieving gender parity in parliament. From the Middle East, Islah Jad reflects on the Palestinian experience at the local government level, Mariz Tadros on the recently applied quota in Egypt, and Sara Abbas on gender politics and how they played out in Sudan. Finally, Sarah Childs presents a thorough gendered reading of the recent elections in the United Kingdom. The types of quota discussed within these articles also vary from party proportional lists in Brazil, Costa Rica and Rwanda, to reserved seats in Egypt, and all women party lists in Sudan and the UK. The political-historical trajectories of these countries dramatically differ: Sierra Leone, Rwanda and Sudan are post-conflict settings, the Occupied Territories is a context of ongoing conflict, Brazil and Bangladesh are post-dictatorship contexts, Costa Rica, India and the UK are consolidated democratic regimes and Egypt and Pakistan are authoritarian regimes under pressure to democratise. Reflecting upon the country experiences conveyed in this IDS Bulletin and beyond, Ana Alice Alcântara Costa shares her reflections on what the quota has meant for the way in which gender and political power have been understood and engaged with theoretically, and in policy.

The aim of this IDS Bulletin is to bring new empirical and conceptual insight from the Pathways programme and beyond to an audience of development academics and policy actors who have become familiar with the proliferation of different forms of affirmative action, but who are interested in interrogating the politics behind the quotas in all their complexity and nuances. It questions some of the prevailing assumptions behind what motivates actors to adopt quotas, it discusses the different political pathways of 
breaking through the ceiling for women to reach political office, whether with or without quotas. Finally this IDS Bulletin raises questions of who are the women who are best positioned to benefit from the quota as a fast track option, what are they enabled to do once in office via the quota seats, and what kind of gender agendas does the critical mass of women who have come to power via the quota espouse and advocate?

\section{Dynamics of introducing quotas: beyond gender equality}

Quotas increase women's representation in parliament, yet what these articles show is that neither the actors nor their motives for adopting affirmative action are necessarily easy to identify. In many cases, the introduction of the quota is not an expression of feminist agency but a coalition of actors who have a vested interest in forwarding a particular agenda. In the case of the Occupied Territories in Palestine, Jad reveals that the quota emerged as a consequence of an alignment of several actors' agendas: Western donors, the Palestinian leadership (Fateh) and a women's coalition whose leader had strong links within the ruling regime. In Rwanda, the Transitional Government of National Unity, which was a coalition of eight political parties, was determined to advance a socially and politically progressive agenda in a post-conflict context and gain legitimacy with a majority women population, and it had backing from international actors, as well as support from various forms of women's actors and coalitions. Many of the articles presented in this IDS Bulletin, hence support Krook's contention that:

the adoption of gender quotas does not always stem from principled concerns to empower women in politics. Rather, most quota policies are the result of combined normative and pragmatic motivations, pursued by varied but multiple groups of actors who support reform for various and often conflicting reasons. As these constellations vary substantially across cases, the relationship between gender quotas and feminist projects of empowerment remains an empirical question, not a theoretical given (Krook 2008: 355).

The motives for adopting quotas are just as diverse as the actors. Khattak's historical analysis of the Pakistani context shows that three military regimes instituted local government reform as a means of deepening and extending their political patronage system, and therefore control over the political process: General Ayub Khan (1958-69), General Zia-ul-Haq (1977-88) and General Pervez Musharraf (1999-2008). The latter was responsible for introducing the 33 per cent quota for women in local government in 2000. These same regimes' introduction of highly reactionary legislation in other spheres suggests that supporting local participation in local government, including that of women was not necessarily part and parcel of championing a women's rights' agenda. For example, under Ziaul-Haq's Islamisation politics, which saw a reversal in many of the achievements that women had gained previously, women were denied their fundamental right to equality in legal matters and rape and murder were recognised as compoundable private crimes.

Abbas' account of regime engagement with the quota in Sudan also points to the introduction of quotas by highly undemocratic regimes to undermine the power base of their opposition as well as to make a statement about their modern credentials. For example, in 1968, Nimeri's government reserved 40 per cent of the seats in the National People's Assembly for women, professionals (which could of course include women), the armed forces, the business community, and other groups that the regime saw as critical in combating the stranglehold of the traditional sectarian parties on rural psyches. Yet the same government also repressed independent women's activisms, calling into question its commitment to advancing a gender equality programme. The Salvationists too, who came to power and represent the current regime would adopt highly inhibitive measures against women under the guise of instituting the Sharia law, while increasing women's political representation in parliament (though as a coopted, pro-government force), and introducing the country's most recent quota.

These examples, and others in this IDS Bulletin suggest that since the quota can often be introduced for complex motives and accompanied by highly inhibitive policies, it should not be seen as a proxy for assessing a country's commitment to democratisation or principles of gender equality. Consequently, the terms of assessing a commitment to women's political empowerment need to be expanded by, 
for example, looking at the gender agendas advocated, discourses, types of legislation enacted, and scope for the active participation of feminist voices (of both women and men).

\section{Negotiating the terms of the quota and beyond}

The form of affirmative action adopted in any particular setting is often an outcome of processes of bargaining and mediation between different stakeholders with different political interests; its full implications for transforming politics (in all kinds of directions) is highly contextualised and dependent on a configuration of a multitude of factors. In much of the literature, the virtues of the proportional representation system are deemed as creating the most enabling conditions for women and for representation of political forces (Childs, this IDS Bulletin), yet the articles here suggest that many more factors influence how power is mediated (Costa Rica before the implementation of sanctions; Brazil, current context; Egypt in the 1970s). As observed by Dahlerup (2009: 25):

It is not just about the electoral system, but how the electoral system works with a constellation of other factors that are crucial for creating an enabling environment. Rwanda, Sweden and Costa Rica represent some of the best cases of gender quotas. They have all achieved a very high level of representation of women. They also represent three different types of electoral gender quota. Rwanda has reserved seats, increasingly based on elections. Two women must be elected from each district. In Rwanda, 56.3 per cent of parliamentarians are women, making it the number one in the world. Sweden has voluntary quotas for party candidate lists. Parties on the left practice 'every second a woman', that is, a 50 per cent voluntary party quota for candidate lists. Right leaning parties do not have quota rules, but to a large extent also alternate male and female candidates on their lists. In Sweden, 47.3 per cent of parliamentarians are women, making it number 2 in the world. Costa Rica has a legislated candidate quota of 40 per cent for all parties.

The diversity in contexts, quota types and electoral systems presented above bears a strong policy message: there are no technical fix-it solutions for arriving at the most perfect type of quota that would create the most enabling conditions for women to claim political power. Certainly, there are very important lessons learnt regarding the need to introduce systems of thorough and rigorous sanctions for noncompliance, as Ballington, Sagot and Araújo argue in their articles. However, in order for these sanctions to be highly effective, they will need to be introduced in other areas as well, such as setting a ceiling for election campaign financing and punishing those who violate it (this is likely to impact many women whose financial resources tend to be more limited, but also have positive equity implications for society as a whole, if implemented well). Other sanctions which are also likely to have a positive gendered impact apply to the use of violence, where it has become engrained in electoral political cultures.

Mechanisms for enforcement and accountability shaped by and designed for local realities and contextual nuances are just as important as addressing the legal loopholes manipulated to avoid application of affirmative action legislation. And for all such processes to work on the ground, the policy focus should not only be on getting the institutional mechanisms right, but on strengthening the capacities of local non-partisan actors who are committed to a holistic approach to gender equality. This would evidently call for a discerning approach to those that advocate gender justice in contrast to those that champion the quotas for instrumental political purposes. Articles in this IDS Bulletin indicate that a strong women's movement plays an important role at the design and implementation stages of the quota. In Rwanda, Kantengwa indicates that the presence of various forms of women's coalitions, strong feminist organisations, and the institutionalisation of effective national machineries all worked together to help set the conditions of a form of quota that would work. In Sierra Leone, Abdullah shows that the 50/50 campaign, the women's parliamentary caucus, and the feminist movement have not only pushed for the institutionalisation of affirmative action but have used their considerable bargaining power to put forward the terms of the quota they deem as appropriate, from their historical and political experience.

The positive correlation between feminist activism (in its many forms) and enhanced capacity support for women's political agency also emerges concretely from the India and 
Bangladesh case studies. In India, Sharma and Sudarshan point to the power of collective feminist agenda enacted through the Uttarakhand Mahila Parishad - UMP (Uttarakhand Women's Federation), a women's movement working in the hill villages. The UMP is a network of around 450 women's groups (Whole Village Groups or WVGs), spread over villages in seven districts of Uttarakhand. Many women members of the WVGs have moved on to contest and win the positions of gram pradham, ward members and block development committee members in the panchayat (village council) elections of 2008. The WVGs nurtured women's leadership, both on a collective as well as individual level, and through a long process of engagement:

Women have over the years acquired the confidence and also the aspiration to affect change through politics and to influence the development agenda. The monthly meetings of the groups have created a space for collectively identifying needs, planning activities, allocating tasks such as cleaning pathways, common village spaces, plantation activity and resolving conflicts that arise within the village (for instance on trespassing cattle, distribution of water, etc.)

In Bangladesh, Nazneen and Tasneem discuss how women who were directly elected to the reserved seats in the Union Parishad (the lowest administrative unit of the local government) urged the women's organisations to raise these issues in different forums on behalf of women members. Conversely, in cases where the women's movement espousing a feminist ideology becomes too weak or fragmented (Sudan at the time of the negotiation of the terms of the quota and Egypt during the process of designing and deliberating the quota), the ultimate outcome is far from what is desired.

From these articles, several positive roles of an engaged local feminist movement can be inferred, including lobbying for policy and legal reform, liaising with international women's actors for knowledge and experience sharing to inform local policy, extension of financial help for women candidates who have limited financial means, support in constituency building, capacity support for candidates and MPs, among a few. However, there are several other areas that provide further opportunities of engagement with the political process for the feminist movement. Abbas argues that in the case of Sudan, a dialogue is needed among women activists from the opposition and the women who have just come to office in the elections of 2010 (all government affiliated) to find scope for engagement on the gender agenda. There are several key policy issues here, including the need to address the disconnect between the feminist movement and various power elites in parliament and government in order to open an avenue for engagement, and possible influence.

Moreover, in negotiating the terms of the quota, one emerging policy area of research is the question of constituency and its centrality (or lack thereof) of how women come to power. In Bangladesh, Nazneen and Tasneem found one of the supporting factors which empowered poor women who were elected into office in local government (Union Parishad) was that they felt they were empowered to represent, and be a voice on behalf of those who elected them. As one female UP member pointedly said:

Oh, they in the parishad say, '[W]hy does a poor woman have such a loud voice? Who is she?' and I remind them, I was elected directly by people in three wards. I am there to represent their views. I have as much right to speak as they do.

(Interview, UP member 2, Pathways Digital

Story Workshop, 20 November 2009).

(Nazneen and Tasneem, this IDS Bulletin)

In Egypt, Tadros highlights the concerns that the conditions of the quota system would delegitimise the importance of a constituency as the pathway to political office. More research is needed about whether women and men engage in constituency building in gendered ways; how class, wealth, political affiliation and forms of community engagement - and the constellation of all of the above in different contexts influence the types of constituencies that are forged; and the extent to which different kinds of quotas inhibit or encourage constituency relationships as the pathway to power.

\section{Pathways and highways of women's accession to political power}

One of the emerging issues in this IDS Bulletin is that while quotas do increase women's numbers in parliament, they are not exclusively the only 
pathway to political power. The case studies here contest the hypothesis put forward by Tripp and Kang that 'All else being equal, countries with quotas have higher rates of female legislative representation than countries without quotas' (2008: 346). It may be that quotas do increase women's presence in parliament, if a before and after methodological approach is taken. However, a cross-country comparison suggests a more nuanced perspective. Ballington's contribution on 'Implementing Special Measures' does reveal that 20 of the top-ranked 26 parliaments use electoral quotas or reserved seats. However, it is also significant that some of the remaining six, which do not have quotas are also very highly placed in the list. For example, Cuba ranks fourth, with 43.2 per cent of seats occupied by women, and Finland ranks sixth, having 40 per cent of parliamentary seats represented by women.

Abdullah's research on Sierra Leone shows that in the 2002 parliamentary elections, women won 18 seats, representing 14.5 per cent of members of parliament - without any kind of affirmative action in place. In Egypt, the highest ever percentage of women in parliament (9.7 per cent) was in the parliamentary round of 1979 (23 June-20 March 1984) when there was a reserved seat quota in place. The difference in percentage of women in parliament between the two countries is quite significant (almost 5 per cent) with the non-quota implementing country faring better. This is not to suggest that quotas are unnecessary (women activists in Sierra Leone continue to struggle to get affirmative action) but it does caution that it would be reductionist to focus on the quota as the only, ultimate pathway to political office. Other effective pathways also need to be considered in tandem with the quota.

It is also important to consider how to prevent the quota from becoming a stalled highway to more women gaining political power due to ineffective implementation. In Brazil, Araújo shows how the quota improved women's representation when it was first applied, but then reached a plateau because, while the law stated there should be a minimum of 30 per cent per sex of the total number of candidates, it also stated that the lists for each party could be up to 150 per cent in relation to the number of seats available for each state. Hence, the quota is calculated not on the actual list of candidates, but on the potential list. Araújo points out that since parties do not have that many candidates, they end up leaving 30 per cent of the seats vacant for women, and rarely fill them. The impact is that the quota has had a maximum ceiling rather than a multiplier effect on increasing women's representation in parliament, for example, in 2006, the numbers of female candidates and females elected remained around the same as they had in 2002. Sagot also presents an account of how counter-strategies had to be deployed in Costa Rica when political parties exploited the existing legal loopholes in the electoral law in order to avoid introducing major changes to their gender hierarchies. This lends further support to the idea of not only redressing inconsistencies in the quota system, but also complementing it with other strategies of enhancing access to political power.

A clear theme emerging from many of the articles which look at enhancing women's pathway to political office, is the question of capacity support. Capacity support features in a number of ways, most commonly in the form of training, but also financial support and constituency building. It is also provided by a variety of actors, including NGOs, governments, national machineries and political parties. Preelection training, in particular by NGOs, has been one of the most popular forms of capacity support provided for women and features in many of the country case studies examined here (Rwanda, India, Bangladesh, Costa Rica, Sierra Leone, Pakistan and Egypt). NGOs providing training has been seen as one way to deal with the significant inequities in women's access to knowledge about political processes, campaign skills and leadership before and after elections. Nazneen and Tasneem's interviews with women elected in the Union Parishad, a significant majority of whom are active in the local shalish (informal arbitration local committees), point to the space created by these formal provisions, supported by various NGO and women's organisations' training programmes, providing relevant legal and human rights training.

On the other hand, several studies indicate that the short cycle nature of the training is an issue: a government nationwide survey of elected women representatives (EWRs) in India, cited in Sharma and Sudarshan's study, showed that just over half received training/orientation. Of those 
wishing training, 82 per cent said the training was too short. The project cycle associated with the provision of training by NGOs may further compound the problem of the lack of sustained learning opportunities provided.

Jad's study of pre-electoral training for women running for local council elections in the Occupied Territories revealed that, while the women's movements and NGOs played an important technical role in training and equipping women for political office with skills such as running an election campaign, leadership and knowledge of the electoral law and local council, once these women were in political office, the training was not sustained. Jad believes that part of the problem is that the funding is for a limited project cycle, which disrupts the continuation of support for women later in their political career. In many respects, the findings from some of the case studies support Morna's observation that:

... initiatives have tended to have a short-term focus on women as candidates rather than on the ongoing support they need in office, or on retention and even exit strategies. There also tends to be a focus on how to run campaigns rather than on how to be effective agents of change. The methods used have tended towards traditional, top-down training, rather than a support approach. Some of the more innovative approaches to adult learning, such as expert on-the-job support, coaching and mentoring, or study and experiential visits have not been used as effectively as they might. Capacity building has almost exclusively focused on empowering women in decision making rather than on what men need to do to share these spaces and to become agents of change. (Morna 2009: 44)

Since many of the capacity building and training schemes are funded by donors, there are relevant policy messages here in terms of shifting the focus from short-term training programmes to longer-term learning initiatives that are diverse in approach and content, sustained during, after, and in between elections and that are more participatory in nature. More comparative research is needed, however, to determine the different capacity building approaches applied in different contexts, for different types and levels of political engagement in order to discover which programmes effectively support women's political pathways.

Further research is also needed in how to engender these programmes so that they do not continue to focus exclusively on women as the 'target beneficiaries'. We also need to examine the appropriateness of different actors as channels for increasing the capacity of candidates. Childs' examination of the training extended by the equality promotion strategy by political parties in the UK shows it has been subject to three main criticisms which speak to the problem of targeting women:

First, aspirant women candidates are known to declare that they, 'don't need any more training'; second, training women to compete according to the current rules of the recruitment game does little to unpack parties' assumptions about what makes a good candidate (Harrison 2006); and finally, training candidates may be insufficient to negate selectorate discrimination against women. Other equality promotion measures, such as the provision of financial assistance, take on greater significance where the cost of fighting party selections is high.

(Childs, this IDS Bulletin)

Childs points to the importance of financial assistance and this is echoed by other case studies where feminist movements and NGOs funding was critical for enabling candidates to overcome hurdles to participation. Some donors are fearful of extending financial support to candidates on the premise that it is a form of partisan political engagement; however, there are many innovative approaches to making the process open, fair and transparent that can be gained from the field.

\section{Quotas for women: a highway for whom and} to do what?

Much of the focus in the literature has been on what kind of quotas work best to increase women's political representation in parliament. With over two decades of sustained efforts to support the quota, it is now timely to examine what kind of women are coming to power under the quotas. Abbas reveals that in Sudan, where all women party lists were implemented in the most recent lower house elections this year (2010), the ruling National Congress Party 
(NCP) won all of the 112 women's seats in parliament, and the majority of the state legislative council seats. In the light of the NCP's long history of a highly reactionary engagement with gender issues, it remains to be seen the extent to which this critical mass of NCP women will deviate from the party line.

The question of who is coming to power via the quota is very pertinent in the light of the changes in political parties' engagement with 'the woman question'. Historically, Left leaning parties have been the most committed to fielding women and introducing internal party mechanisms to break the glass ceilings inhibiting women assuming leadership positions (also inferred from the case studies presented here, e.g. Brazil, Occupied Territories, Costa Rica, Egypt and the UK). However, more recently, Right wing parties and forces have also been increasingly fielding women who are politically affiliated. While no generalisations can be made about the way in which they exercise their agency within the party nor about the agendas they espouse, there is a pressing need for comparative country studies of the performance of women from right wing parties where they represent the larger proportion of women in parliament, and where they have reached office through the quotas.

The agenda that is in question is not only the gender agenda, but more broadly, the social justice agenda. Many of the articles in this IDS Bulletin show a concern for elitist women coming to power (see Kantengwa, Sagot, Tadros and others). Sagot points out that in Costa Rica:

the passing of the quota legislation has also meant the arrival into power of many conservative women, closely connected to political and economic elites, who do not have any progressive agendas and who, in fact, act as strong opponents of the feminist movement, particularly on those issues related to sexual and reproductive rights.

She gives the example of the discussions on the Bill to Criminalise Violence Against Women in 2007, in which the President of the Congressional Women's Commission ${ }^{2}$ in charge of analysing all law proposals related to women's issues, disagreed with the Bill, arguing that, on many occasions, women provoke family violence and the important thing was not to create more privileges for women, but to preserve the sanctity of the family. ${ }^{3}$ On another occasion, women legislators expressed their opposition to a Bill that proposed an eight-hour work-day for domestic workers, arguing that they could no longer participate in politics if their domestic workers did not work extended hours. Rosita Acosta, president of the Domestic Workers Association, told these women legislators at a public hearing, 'What you want is a slave and not a domestic worker'. ${ }^{4}$ With more and more women from different political forces coming to power via the quota, this is an appropriate time to test the contention that 'improving women's legislative representation is crucial to addressing women's strategic political needs' (Lindberg 2004: 30). Since the last decade has brought to power or consolidated the power of highly conservative regimes, we need comprehensive, comparative research on how this has translated into women's agency through parliamentary outputs, implementation and having a wider social and political effect.

\section{Future policy directions}

The focus in recent years through international frameworks on building momentum for the adoption of quotas has had important ripple effects. With more women in parliament today than previously, this is an opportune moment to broaden the policy messages on two fronts. The first is to identify other key power bases (e.g. key ministries) where gender hierarchies have remained unchallenged. Parliament has been the focus of much policy advocacy aimed at increasing women's political decision-making power, which is justifiable, given the persistent levels of gender inequality (17.9 per cent of women on average worldwide in 2010, as highlighted by Ballington's article). However, parliament is not the only site where political power is exercised, and hence the need for a contextualised understanding of the different sites and pathways in which power is reproduced. The implications of keeping the debate strictly on political decision-making in parliament is that a piecemeal approach is applied, offering limited opportunities for greater transformative change in how power is exercised.

The second front in policy directions is to examine not only how many women are in any parliament, but what kind of gender agendas they have espoused and what has been their influence on social and gender justice issues. The quota, like all policies and measures aimed at 
promoting gender equality, can be instrumentalised by forces for whom gender empowerment is secondary to other goals (i.e. giving the semblance of being modern or progressive or democratic) or conversely, for those with highly reactionary gender agendas. It is critical therefore that the policy focus goes beyond the representative dimension of gender parity in parliament to examine how the critical mass is engaging with gender issues, and what kind of legislation is advanced. The implications of stopping at getting the numbers right is that we may end up, inadvertently, legitimising, in some cases, the promotion of agendas antithetical to gender justice under the guise that they have been advanced by women. It may also mean that in practice, one of the policy directions is not only to support parties with the largest number of women but those who have supported the most progressive gender agendas in parliament, even if the advocates are a group of gender-sensitive men as well as women.

Since one of the pathways most sought for women's political empowerment is to provide capacity development for the enhancement of their skills and abilities to field the electorate process or undertake their duties once in office, this is an ideal time to undertake a comprehensive contextsensitive comparative study of the providers, the approaches, and the implications on the ground for communities where such initiatives have been pursued. From the articles presented here, we can glean subtle messages about where there is a pattern emerging in response to initiatives implemented. Successful ventures, which have proven to be particularly powerful are cross-country experiential learning visits. These allow participants to expand horizons and see issues and processes from different perspectives. Moreover, the articles here also suggest that reimagining capacity support as entailing long-term learning processes rather than a series of short training opportunities will also strengthen the ability of these programmes to deliver. It will also help in recognising that pathways to political power require an investment in a sustained process of support rather than being seen as a pre-election ploy to fast track women to political power.

There is an emerging need for unconventional approaches for enhancing capacity that recognise the need for context-sensitive approaches and that recognise the need for both individual as well as collective strategies of engagement (e.g. finding appropriate ways, where relevant, of integrating men as partners in women's leadership programmes). This may 'target' those who are considering political office, but it may involve targeting key influential actors in the community, who if joined in a coalition would play an influential role in creating an enabling environment for challenging gender hierarchies. Recognising the need to provide capacity support to engage in the informal political realm not just the formal institutions, such as enhancing the ability to liaise and build relationships between the women's movement and political actors within parliament and other sites of influence and power, is also significant.

Finally, despite the richness of the case studies presented in this IDS Bulletin and the wealth of rich literature on the effectiveness of quotas, we know very little about where the opportunities for learning by doing politics (apprenticeship possibilities) lie. Certainly political parties have been rightfully the site of policy influence, however, in light of the complexity of regime types and changes in the political economy, we need to capture what other avenues have been influential in different contexts. For example does leadership in local government act as a stepping stone to national representation? What about engagements through non-governmental organisations? And feminist movements? And right wing religious and social movements? These questions are not only likely to influence policies adapted with respect to the nature of local capacity building initiatives but also how we conceptualise pathways and highways to political power. The quota may have been the motorway through which women rose to power en masse, and its contributions to changing the gendered face of parliament cannot be underestimated. However, it is now time to also consider policy emphases equally on other pathways, that may not necessarily represent fast track options to power, but which are significant for political empowerment. These pathways may be slow sometimes, such as building strong constituencies or investing in the younger generations of gender sensitive men and women and they cannot be 'fixed' through external incentives such as a quota, but they can represent in and of themselves, opportunities of transforming gender hierarchies, not just in their outputs but through the very processes that are walked. 


\section{Notes}

1 'Pathways' is an international research and communications programme established in 2006 and is supported by the UK Department for International Development (DFID), the Norwegian Ministry of Foreign Affairs and the Swedish Ministry for Foreign Affairs, working in Afghanistan, Bangladesh, Brazil, Egypt, Ghana, Nigeria, Pakistan, Palestine, Sierra Leone and Sudan, and in global policy spaces.

\section{References}

Dahlerup, Drude (2009) 'Is Parliament Open to Women? Quotas in Global Perspective', in 'Is Parliament Open to Women? An Appraisal', Conference for Chairpersons and Members of Parliamentary Bodies Dealing with Gender Equality, Geneva Inter-Parliamentary Union

Dahlerup, Drude (2003) 'Quotas are Changing the History of Women', paper presented at the International Institute for Democracy and Electoral Assistance (IDEA)/Electoral Institute of Southern Africa (EISA)/Southern African Development Community (SADG) Parliamentary Forum Conference, www.quotaproject.org/CS/CS_Drude_Africa_ Oct_2004.pdf (accessed 6 July 2010)

Harrison, L. (2006) 'Women's Legislative Representation - Do Political Parties Utilize a Gendered Model of the "Good Candidate"?', unpublished paper

Krook, Mona (2008) 'Quota Laws for Women in Politics: Implications for Feminist Practice', Social Politics 15: 345-68

Lindberg, S. (2004) 'Women's Empowerment and Democratization: The Effects of Electoral Systems, Participation, and Experience in Africa', Studies in Comparative International Development 39.1: 28-53
2 Legislator Gilda González from the Partido Liberación Nacional.

3 Information provided by Gabriela Arguedas, former legislative aide.

4 Information provided by Rosita Acosta, President of the Domestic Workers Association.

Morna, Colleen (2009) 'Is Parliament Open to Women? Quotas in Global Perspective', in 'Is Parliament Open to Women? An Appraisal', Conference for Chairpersons and Members of Parliamentary Bodies Dealing with Gender Equality, Geneva Inter-Parliamentary Union Tripp, Aili and Kang, Alice (2008) 'The Global Impact of Quotas on the Fast Track to Increased Female Legislative Representation', Comparative Political Studies 41.3: 338-61

UN (2006a) Millennium Project, www.unmillennium project.org (accessed 12 July 2010)

UN (2006b) Millennium Project: Goals, Targets and Indicators, www.unmillenniumproject.org/ goals/gti.htm\# goal3 (accessed 12 July 2010)

UN (1985) Report of the World Conference to Review and Appraise the Achievements of the United Nations Decade for Women: Equality, Development and Peace, 15-26 July, Nairobi, www.un.org/womenwatch/ confer/nfls/Nairobi1985report.txt (accessed 12 July 2010)

United Nations Division for the Advancement of Women (UN DAW) (n.d.) 'The United Nations Fourth World Conference on Women', www.un.org/womenwatch/daw/beijing/platform/ decision.htm (accessed 12 July 2010) 